\title{
PERKEMBANGAN TAFSIR DI INDONESIA ( PRA KEMERDEKAAN 1900-1945)
}

\author{
Rifa Roifa, Rosihon Anwar, Dadang Darmawan \\ Fakultas Ushuluddin UIN Sunan Gunung Djati Bandung \\ Jl.A.H.Nasution 105 Cibiru Bandung 40614, Indonesia \\ E-Mail : rifa.roifa@yahoo.com
}

\begin{abstract}
Abstrak
Pada paruh pertama abad ke-20 karya-karya tafsir mulai bermunculan dan berkembang pesat di Nusantara. Hal ini merupakan fenomena baru, karena pada abad-abad sebelumnya, karya-karya tafsir Nusantara sangat jarang ditemukan.Ditambah kondisi Indonesia pada masa sebelum masa kemerdekaan berada dalam keadaan yang cukup sulit dan rumit. Kitab tafsir yang ditulis oleh para mufasir Indonesia saat itu, berupaya membangkitkan semangat bangsa untuk lepas dari penderitaan walaupun hanya dengan pernyataan yang samar-samar. Penelitian ini memfokuskan diri pada masalah perkembangan tafsir di Indonesia dari tahun 1900-1945, dilihat dari karakteristiknya yang meliputi aspek metode, sumber dan corak penafsiran, sebagaimana terlihat pada karya-karya tafsir yang lahir pada masa itu. Penelitian ini merupakan penelitian studi kepustakaan atas empat karya tafsir dari tahun 1900-1945 sebagai sumber data primer yaitu; Tafsir Al-Qurān Karīm, Tafsir Al-Furqan, Tafsir Malja AlThalibin, dan Tamsiyah Al-Muslimin. Penelitian ini lebih bersifat deskriptif-analitis dengan menggunakan pendekatan historis. Dari penelitian yang telah dilakukan, ditemukan data-data sebagai berikut: untuk metode penafsiran yang terdapat pada ketiga tafsir ini yaitu, tafsir Al-Qurān Karīm, tafsir Al-Furqan, dan tafsir Malja AlThalibinmenggunakan metode Ijmāli. Sedangkan untuk tafsir Tamsyiah Al-Muslimin ialah Tahlïli. Sumber penafsiran pada keempat tafsir tersebut masing-masing dari karya tersebut semua sumbernya ialah bil ra'yi.Untuk corak tafsir yang terdapat pada kedua tafsir ini yaitu tafsir Al-Qurān Karïm, dan Tamsyiah Al-Muslimin adalah corak adab al-ijtim'i.Pada tafsir Al-Furqān adalah corak lughawi.Adapun pada tafsir Malja Al-Thalibin tidak ada corak yang dominan, adakalanya Sanusi menafsirkan ayat yang berhubungan dengan masalah fiqih, kalam, atau sufi,ini menunjukan bahwa sifat coraknya adalah umum. Dengan demikian, dapat diambil kesimpulan bahwa pada keempat tafsir ini karena berada pada masa pra kemerdekaan, tentu saja di dalam penafsirannya ada sedikitnya ayat-ayat yang menyentuh mengenai motivasi pada semangat perjuangan seperti misal contoh yang ada pada ayat 85 surah $\mathrm{Al}$ Baqarah dan ayat 71 surah Al-Taubah, yang membuktikan bahwa penulisan karya tafsir pada masa ini ada kaitannya dengan persoalan sosio-politik yang terjadi dan bahkan dapat menjurus kepada jawaban-jawaban dari masalah yang terjadi, yang merupakan suatu ciri khas dari karya-karya tafsir masa itu.
\end{abstract}

\section{Kata Kunci :}

Perkembangan tafsir; Pra Kemerdekaan ; Metode; Sumber.

\begin{abstract}
In the beginning of the 20th cerntury, several tafsir emerged and developed significantly in Indonesian archipelago. This phenomenon was exceptional because there were no documentation on tafsir writing in Indonesia in the centuries before. It was understandable because of Indonesian condition before independence was tough and threatening. Thus, the content of tafsir written by Indonesian scholars in this era indicated (indirectly) to raising the spirit to escapefrom suffering of collonialisation. This article attempts to investigate the development of tafsir in Indonesia from the periode of 1990 to 1945. This article focuses on the analysis of four tafsir namely: Tafsir AlQurān Karim, Tafsir Al-Furqan, Tafsir Malja Al-Thalibin, dan Tamsiyah Al-Muslimin related to their methods, sources and approaches. This article based on library research on four tafsir employing descriptive analytical study and historical approach. This article shows that the methods used in three tafsir such as tafsir Al-Qurän Karīm, tafsir Al-Furqan, and tafsir Malja Al-Thalibin are ijmaly (global). Meanwhile, in tafsir Tamsyiah Al-Musliminthe author used Tahlili (analytical) method. The source of interpreting the Qur'an for these four tafsir are bil ra'yi (rational).In term of approach, the two tafsir (tafsir Al-Qurān Karīm, andTamsyiah Al-Muslimin) employed adab alijtim 'i (literary and social). Tafsir Al-Furqān used lughawi.(linguistics) approach in understanding the Qur'an, while tafsir Malja Al-Thalibin no indication of following dominant approach but it was a combination between fiqih, kalam, and sufi. In these four tafsir, the socio political aspects were emerged to encourage Indonesian people to fight for independence.
\end{abstract}

Keywords:

The development of Tafsir; Pre Independence, Methods, source. 


\section{A. PENDAHULUAN}

Upaya penulisan tafsir di Indonesia juga sudah lama berjalan, dimulai dari karya Abd Al-Rauf Singkili Tarjuman al-Mustafid, dalam tulisan Arab Melayu pada abad ke-17, hingga Tafsir Rahmat karya H. Oemar di abad ke-20 ini. Pada masa kurang lebih tiga abad itu telah banyak tafsir Alquran yang dihasilkan. Namun, tidak didapatkan keterangan apakah di setiap abad itu terdapat tafsir Alquran. Walaupun terdapat informasi, Syaikh Nawawi Banten menulis tafsirnya yang berjudul Tafsir Maroh Labib pada abad ke-19, tetapi tafsir ini terbit di Mekah pada permulaan tahun 1880 . Agaknya penulisan tafsir yang terbanyak barulah pada adab ke-20. Di samping ada tafsir yang berbahasa Indonesia ada pula yang berbahasa daerah, antara lain: Tafsir Hibarna oleh KH. Iskandar Idris (1960), Al-Quran Jawen dan Al-Quran Sundawiyah (Solo: AB Siti Samsiah, tanpa tahun) dan lain-lain. ${ }^{1}$

Akhir tahun 1920-an, sejumlah terjemahan Alquran sudah dalam bentuk juz per-juz, bahkan seluruh isi Alquran mulai bermunculan. Bahkan dalam periode awal abad ke-20 tradisi tafsir di Indonesia bergerak dalam model dan teknis yang sudah cukup berkembang. Kondisi penerjemahan Alquran semakin kondusif setelah terjadinya sumpah pemuda pada tahun 1928 yang menyatakan bahwa bahasa persatuan adalah bahasa Indonesia. Tafsir Al-Furqānmisalnya adalah salah satu tafsir pertama yang diterbitkan pada tahun 1928. ${ }^{2}$ Perkembangan penafsiran Alquran agaknya berbeda dengan perkembangan yang terjadi di dunia Arab yang merupakan tempat turunnya Alquran. Oleh karena itu, proses pemahaman Alquran terlebih dahulu dimulai dengan penerjemahan Alquran ke dalam bahasa Indonesia, baru kemudian setelah itu dilanjutkan dengan

${ }^{1}$ M. Amin Aziz, Jurnal Ilmu Dan Kebudayaan Ulumul Quran, "Karakteristik Tafsir di Indonesia Abad Keduapuluh," (Jakarta: Lembaga Studi Agama dan Filsafat (LSAF) dan Ikatan Cendikiawan Muslim se Indonesia, 1992), Volume III. No. 4, 51.

${ }^{2}$ Nashruddin Baidan, Perkembangan Tafsir AlQur'an di Indonesia, (Yogyakarta: Pustaka Mandiri, 2003), 62 . penafsiran yang lebih luas dan rinci. ${ }^{3}$ Dalam periode ini, karya-karya tafsir di Nusantara bermunculan dan berkembang pesat, hal tersebut dibuktikan dengan adanya karyakarya tafsir yang telah mereka wariskan. Tradisi tafsir di Indonesia bergerak pada model dan teknis penulisan yang masih sederhana. Dari segi material, teks Alquranlah yang menjadi objek tafsir, literatur tafsir periode ini cukup beragam. Diantaranya ; Pertama, ada literatur tafsir yang berkonsentrasi pada surat-surat tertentu. sebagai objek penafsiran, misalnya; Tafsir Alquran Al-Karim,Yasin (Medan: Islamiyah, 1951) karya Adnan Yahya lubis dan Tafsir Surat Yasin dengan keterangan (Bangil: Persis, 1951) karya A. Hassan.Kedua, karya literarur tafsir yang berkonsentrasi pada juzjuz tertentu dengan muncul hanya juz 30 (Juz Amma) yang menjadi objek tafsir. Contoh dari model ini adalah: Al-Burhan, Tafsir Juz Amma (Padang: Al-Munir, 1922) karya H. Abdul karim Amrullah. Ketiga, ada yang menafsirkan Alquran secara utuh 30 juz, yaitu misal, Tafsir Al-Qurān Karìm (Jakarta: Pustaka Mahmudiyah, 1957cetakan VII) karya H. Mahmud Yunus yang pertama kalinya diselesaikan penulisannya pada tahun 1938 dll.

Di Indonesia pada masa ini tepatnya sebelum masa kemerdekaan adalah keadaan yang rumit, sebab kondisi Indonesia pada saat itu dalam keadaan terjajah oleh penjajahan Jepang dan sebelumnya oleh Belanda yang kurang lebih sampai tiga abad setengah, yang tentunya sangat mempengaruhi psikologis masyarakat Indonesia dan kondisi ini tentu saja dapat mempengaruhi khazanah tafsir yang ada di Indonesia. Ditambah lagi problem internal munculnya gerakan nasionalis salah satunya yang kala itu sedang marak, ditambah lagi dengan permasalahan Indonesia yang menghadapi berbagai problematika dalam hal menyiapkan proklamasi kemerdekaan.

Dengan demikian, keberadaan kitab tafsir yang ditulis oleh para mufasir Indonesia

\footnotetext{
${ }^{3}$ Sulaiman Ibrahim, Pendidikan dan Tafsir “Kiprah Mahmud Yunus dalam Pembaruan Islam", (Jakarta: LEKAS, 2001), 80.
} 
salah satunya untuk membangkitkan semangat bangsa walaupun hanya dengan pernyataan yang samar-samar, juga merespon atau menjawab tantangan zaman yang kala itu sedang dalam keadaan yang sulit. Inilah sebabnya ketertarikan penulis akan meneliti lebih lanjut bagaimana perkembangan tafsir di Indonesia sebelum masa kemerdekaan dan bagaimana karakteristik tafsir dilihat dari aspek metode, sumber dan corak karya-karya tafsir di Indonesia dari tahun 1900-1945.

\section{B. PEMBAHASAN}

\section{Pengertian Karakteristik Tafsir}

Secara etimologi, istilah karakteristik tafsir tersusun dari dua kata, yaitu kata "karakteristik dan tafsir". Istilah karakteristik terambil dari bahasa Inggris yakni characteristic, yang maknanya mengandung sifat khas. Dalam Kamus Bahasa Indonesia edisi elektronik (2008) karakteristik, mempunyai sifat khas sesuai dengan perwatakan tertentu.

Sedangkan kata tafsir berasal dari kata alfasr yang artinya adalah menjelaskan dan mengungkapkan makna. kata tafsir secara etimologi merupakan bentuk mashdar dari "فسرّ - يفسّر -تفسير ا " (fassara yufassiru), yang secara terminilogi mengandung banyak pengertian: misal salah satu contoh bahwa tafsir berarti menerangkan dan menjelaskan الإيضاح و التبيين (al-idhah wa altabyin), yaitu ada sesuatu yang semulanya tidak ada atau mungkin belum ada dan memerlukan penjelasan lebih lanjut, sehingga jelas dan terang. Contohnya firman Allah ta'ala dalam Alquran:
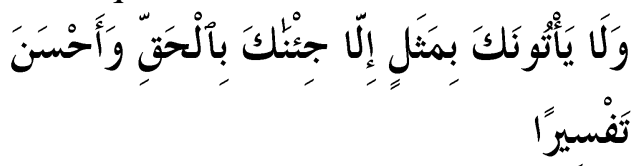

"Tidaklah orang-orang kafir datang kepadamu (membawa) sesuatu yang ganjil, melainkan kami datangkan kepadamu suatu yang benar dan yang paling baik penjelasannya" (Q.S AlFurqān[25]: 33)."

Al-Tabari menyebutkan pada tafsirnya bahwa makna "tafsira" dalam ayat ini maknanya adalah penjelasan dan perincian.
Hal ini juga disebutkan oleh Jalaludin AsSuyuti dalam tafsirnya. ${ }^{4}$

Dengan demikian tafsir adalah suatu ilmu yang di dalamnya berupaya untuk mengungkapkan isi kandungan ataupun makna-makna yang terkandung dalam ayat Alquran. Selanjutnya, yang dimaksud dengan karakteristik tafsir ialah suatu sifat yang khas yang melekat dan dapat dijadikan ciri untuk mengidentifikasi suatu penafsiran. Misalnya metode, sumber, laun (corak), teknik penafsiran, sistematika, dan lain sebagainya. Namun istilah karakteristik sebuah tafsir dalam Ulum al-Tafsir sering diidentifikasikan lewat metode penafsiran, sumber penafsiran dan pendekatan atau corak pemikiran penafsiran.

\section{Pengertian Metode, Sumber dan Corak penafsiran}

Berbicara mengenai karakteristik tafsir maka barang tentu di dalamnya membahas mengenai kajian dalam aspek metode, sumber dan corak atau pendekatan penafsiran. Adapun ranah yang akan penulis bahas pertama yakni yang meliputi tiga aspek berikut ini, yaitu;

\section{a. Metode penafsiran}

Untuk pembagian metode tafsir sendiri dibagi empat. ${ }^{5}$ 1) Metode Tahlili, metode tafsir tahlili biasanya diartikan dengan analisis. Yaitu suatu metode tafsir yang mufasirnya berusaha menjelaskan kandungan makna ayat-ayat Alquran dari berbagai aspeknya, dengan memperhatikan urutan ayat sebagaimana yang tercantum dalam mushafnya. 2) Metode Ijmāli, metode Ijmāli adalah suatu metode tafsir yang mufasirnya berusaha untuk menjelaskan kandungan makna ayat-ayat Alquran secara global tanpa uraian yang panjang lebar. Contohnya seperti;

\footnotetext{
${ }^{4}$ Imam Al-Ṭabārīi, Tafsir Al-Ṭabārīi, Juz VI Kairo: Maktabah Ibnu Taimiyah, 387. Lihat juga Tafsir Jalalain Al-Suyuti Maktabah Syamilah edisi ketiga.

${ }^{5}$ Keempat metode adalah metode penafsiran yang disepakati oleh para ahli tafsir. Hal ini dapat dilihat dari berbagai sumber yang ada. Di antara tokoh yang membagi seperti ini adalah a) 'Abd Al-Hayy AlFarmawi, ia menggunakan istilah manhaj untuk menyebut metode tafsir. b) Ibrahim al-Dasuqi Khamis dengan istilah manhaj.
} 
Tafsir Jalalain. 3) Metode Muqaran, metode tafsir muqaran adalah metode yang ditempuh mufasir dengan cara mengambil sejumlah ayat Alquran, kemudian mengemukakan pendapat para mufasir tentang penafsiran ayat tersebut, baik ulama salaf maupun khalaf yang bersumber manqul atau ra'yu. ${ }^{6}$ 4) Metode Maudu'i, menurut pengertian istilah para ulama adalah menghimpun seluruh ayat Alquran yang memiliki tujuan dan tema yang sama. ${ }^{7}$

\section{b. Sumber Penafsiran}

Macam-macam penafsiran dilihat dari sumbernya maka terbagi menjadi dua, pertama, tafsir bi al-mathur dan kedua, tafsir bi al-Ra'yí. Namun, sebagian ulama ada yang menambah tafsir bi al-Isharah, yaitu menafsirkan dengan cara firasat atau kekuatan intuitif yang biasanya dimiliki oleh para tokoh-tokoh shufi, sehingga sering juga disebut dengan tafsir shufi. Tafsir bi al-mathur adalah tafsir yang berlandaskan naql yang shahih, dengan cara menafsirkan Alquran dengan Alquran atau sunnah, yang merupakan orang-orang yang paling tahu tentang kitabullah, atau perkataan tabi'in yang belajar tafsir langsung dari para sahabat. ${ }^{8}$

Tafsir bi al-Ra'yi, berasal dari kata al$r a y^{\prime}$, secara etimologis bermakna keyakinan, qiyas dan ijtihad. Jadi, tafsir bi al-Ra'yí itu adalah penafsiran yang dilakukan dengan cara ijtihad, yaitu rasio yang dijadikan titik tolak penafsiran. ${ }^{9} R a{ }^{\prime} y u^{-}$semata yang tidak disertai bukti-bukti akan membawa penyimpangan terhadap Kitabullah. Kebanyakan orang melakukan penafsiran dengan semangat demikian adalah ahli bid'ah, penganut

\footnotetext{
${ }^{6}$ Badruzzaman M. Yunus dan Eni Zulaiha, Metodologi Tafsir Klasik,80-84.

${ }^{7}$ Abdul Hayy Al-Farmawi, Metode Tafsir Maudhu'i dan Cara Penerapannya, terj. Rosihon Anwar, cet. 1, (Bandung: CV. Pustaka Setia, 2002), 4344.

${ }^{8}$ Manna' Al-Qattan, Mabahits fī Ulüm Al-Qur'àn, Terj: Aunur Rafiq el-Mazni, (Jakarta: Pustaka alKautsar, 2006), 358.

${ }^{9}$ Muhammad Al-Fatih Suryadilaga dkk, Metodologi Ilmu Tafsir, (Yogyakarta: Teras. 2010), 306.
}

mazhab batil. ${ }^{10}$ Adapun status tafsir bila dengan ijtihad semata tanpa ada dasar yang shahih adalah haram. Sebagaimana firmn Allah swt:

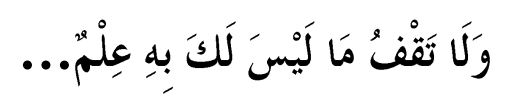

"Dan janganlah kamu mengikuti apa yang kamu tidak mempunyai pengetahuan tentangnya." (Q.S al- Isrā [17]: 36)."11

\section{c. Corak Penafsiran}

Corak penafsiran Alquran atau disbeut dengan laun ialah hal yang tak dapat dihindari, Berbicara mengenai karakteristik dan corak sebuah tafsir, di antara para ulama yang membuat pemetaan dan kategorisasi yang berbeda-beda, ada yang menyusun bentuk pemetaannya dengan tiga arah, yaitu; yang pertama adalah metode (misalnya; metode ayat antar ayat, ayat dengan hadis, ayat dengan kisah Israiliyyat), yang kedua, teknik penyajian (misalnya; teknik runtut dan topikal), dan yang ketiga, pendekatan (misalnya; fiqih, falsafi, sufi dan lain-lain). ${ }^{12}$

Adapun di Indonesia yang dikategorikan tafsir sufi seperti yang telah katakana oleh penelitian sebelumnya adalah Tarjuman alMustafid karya Abd Rauf Al-Singkili. Kedua, tafsir yang bercorak fiqh adalah tafsir yang cenderung dengan metode fiqih sebagai basisnya, atau dengan kata lain tafsir yang berada di bawah pengaruh ilmu fiqih, karena fiqih itu sudah menjadi minat dasar mufassirnya sebelum dia melakukan upaya penafsiran. ${ }^{13}$ Tafsir semacam ini seakan-akan melihat Alquran sebagai kitab suci yang berisi ketentuan perundang-undangan, atau menganggap Alquran sebagai kitab hukum. ${ }^{14}$ Ketiga, yaitu tafsir yang bercorak falsafi, yang mana kecenderungan tafsirnya itu

\footnotetext{
${ }^{10}$ Manna' Khalil Al-Qattan, Studi Ilmu-Ilmu AlQur'an, 488.

${ }^{11}$ Manna' Khalil Al-Qațan, Studi Ilmu-Ilmu AlQur'an, 489.

${ }^{12}$ Muhammad Al-Fatih Suryadilaga dkk, Metodologi Ilmu Tafsir, 12.

${ }^{13}$ Abdul Mustaqim, Aliran-Aliran Tafsir; dari Periode Klasik Hingga Kontemporer, (Yogyakarta: Kreasi Warna, 2005), 70.

${ }^{14}$ Taufik Adnan Amal, dkk,Tafsir Kontekstual AlQur'an, (Bandung: Mîzan, 1990), 24.
} 
dengan menggunakan teori-teori filsafat, atau tafsir dengan dominasi filsafat sebagai pisau bedahnya. Tafsir semacam ini pada akhirnya tidak lebih dari deskripsi tentang teori-teori filsafat. ${ }^{15}$ Keempat, tafsir yang bercorak ilmi, adalah tafsir yangcenderung menafsirkan Alqurannya itu dengan memfokuskan penafsiran pada kajian bidang ilmu pengetahuan, yaitu untuk menjelaskan ayatayat yang berkaitan dengan ilmu dalam Alquran. ${ }^{16}$

Kelima, tafsir adab al-ijtimá, $i$ ini adalah tafsir yang memiliki kecenderungan kepada persoalan sosial kemasyarakatan. Tafsir jenis ini lebih banyak mengungkapkan hal-hal yang berkaitan dengan perkembangan kebudayaan masyarakat yang sedang berlangsung.

Keenam, tafsir yang bercorak lughawi, ialah sebuah tafsir yang cenderung kepada bidang bahasa. Penafsirannya meliputi segi i'rab, harakat, bacaan, pembentukan kata, susunan kalimat dan kesusastraannya. Tafsir semacam ini selain menjelaskan maksudmaksud ayat-ayat Alquran, tapi juga menjelaskan segi-segi kemu'jizatannya. Ketujuh, tafsir bercorak teologi(Kalam), ialah tafsir dengan kecenderungan pemikiran Kalam, atau tafsir yang memiliki warna pemikiran kalam. Tafsir semacam ini adalahsalah satu bentuk penafsiran Alquran yang tidak hanya ditulis oleh simpatisan kelompok teologis tertentu, tetapi lebih dari itu merupakan tafsir yang dimanfaatkan untuk membela sudut pandang teologi tertentu. Paling tidak, tafsir model seperti ini akan lebih banyak membicarakan tema-tema teologis dibandingkan mengedepankan pesan-pesan pokok Alquran. Salah satu kitab tafsir yang bercorak teologi adalah Tafsir Mu'tazilah. ${ }^{17}$

\section{Sejarah Penulisan Tafsir di Indonesia \\ a. Abad ke-16 hingga abad ke-17 (abad pertengahan)}

\footnotetext{
${ }^{15}$ Muhammad Husein al-Dzahại, Al-Tafsirir Wa Al-Mufasirụn, ( Al-Qahirah:, Maktabah Wahbah 2000), Juz II, 419.

${ }^{16}$ Abd. Kholid, Kuliah Madzahib Al-Tafsir, 69.
${ }^{17}$ Abdul Mustaqim, Aliran-Aliran Tafsir, 70.
}

Sebenarnya kita bisa mencatat bahwa pada abad ke-16 di Nusantara telah muncul proses penulisan tafsir. Buktinya telah ditemukan naskah tafsir surat al-kahfi [18]: 9 yang ditulis pada masa-masa itu, meskipun belum diketahui siapa penulisnya, ${ }^{18}$ teknik tafsir ini ditulis secara parsial berdasarkan surat tertentu. ${ }^{19}$ Manuskrip ini tertanggal sebelum tahun $1620 \mathrm{M}$ dibawa ke Belanda yaitu tafsir surah al-kahfi dalam bahasa Melayu namun tidak tercantum pengarangnya.

\section{b. Abad ke-18 dan ke-19 (abad pra modern)}

Pada abad ke-18 muncul beberapa ulamaulama sebagai penulis dalam berbagai disiplin ilmu termasuk tafsir, meskipun yang paling menonjolnya adalah karya yang terkait mistik atau tasawuf, seperti dalam kitab Sayr alSalik, yang ditulis oleh Al-Palimbani dari ringkasan kitab Ihya 'Ulum al-Din karya AlGhazali.

\section{c. Abad ke-20 (abad modern sampai tahun 1945)}

Sejak akhir tahun 1920-an dan seterusnya, sejumlah terjemahan Alquran sudah dalam bentuk juz per-juz, bahkan seluruh isi Alquran mulai bermunculan. ${ }^{20}$ Kondisi penerjemahan Alquran semakin kondusif setelah terjadinya sumpah pemuda pada tahun 1928 yang menyatakan bahwa bahasa persatuan adalah bahasa Indonesia. Tafsir Al-Furqān misalnya adalah tafsir pertama yang diterbitkan pada tahun $1928 .^{21}$

\section{Analisis Terhadap Metode Penafsiran a. Tafsir Al-Qur'ān Karim ${ }^{22}$}

\footnotetext{
${ }^{18}$ M. Nurdin Zuhdi, Pasaraya Tafsir Indonesia, (Yogyakarta: Kaukabapa. 2014), cet. I. 61.

${ }^{19}$ Islah Gusmian, Khazanah Tafsir Indonesia: dari Hermeneutika Hingga Ideologi, 53.

${ }^{20}$ Karya awal tentang terjemahan Al-Qur'an adalah Tafsir Al-Qur'an Al-Karim yang disusun oleh Mahmud Yunus, (Jakarta: dimulai tahun 1922 dan dicetak pertama kalinya secara keseluruhan tahun 1938).

${ }^{21}$ Nashruddin Baidan, Perkembangan Tafsir AlQur'an di Indonesia, 62.

${ }^{22}$ Tafsir ini mulai ditulis pada tahun 1922 yang diterbitkan tiga juz dengan huruf Arab-Melayu. Kemudian ditulis kembali pada tahun Desember 1935 dengan menafsirkan pada ayat-ayat yang dianggap
} 
Karya tafsir yang ditulis oleh Mahmud Yunus $^{23}$ (gambar 1 cover tafsir Al-Qur'ān Karim) yang terdiri dari satu jilid ini sistematika penulisannya diawali dengan muqadimah pengarang di mana isi muqadimah tersebut adalah latar belakang penulis tafsir, selanjutnya langsung masuk pada pembahasan ayat-ayat Alquran. Adapun cara penulisan Tafsir al-Qur'ān Karim ialah ayat demi ayat dan surah demi surah sesuai dengan urutan yang ada dalam mushaf Alquran yang ada sekarang ini dan penafsirannya dilakukan secara umum (global) tanpa uraian yang panjang lebar pada setiap ayatnya. Dengan cirinya ${ }^{24}$ memberi catatan kaki (footnote), juga menerangkan ayat satu digabung dengan ayat lain, misalnya, salah satunya penjelasan surah Al-Baqarah ayat 67-73, ayat 111-112 dan banyak lagi.

Gambar 1 Cover Tafsir Mahmud Yunus

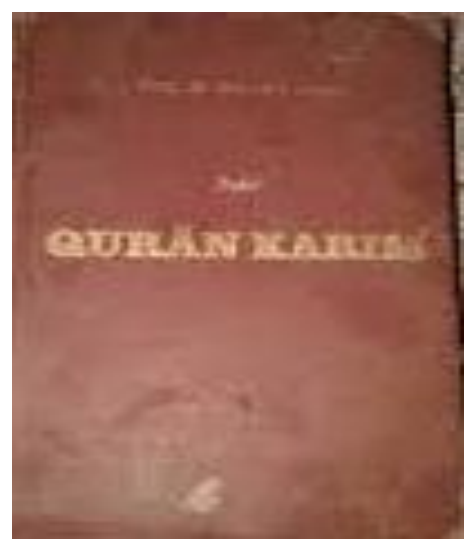

penting, dan Mahmud Yunus memberi nama tafsir ini dengan "Tafsir Al-Qur'an Karim" dengan susah payah diterbitkan berjuz 2 setiap bulan, sedang juz 7 s/d 18 tafsir ini dibantu oleh Almarhum H.M.K Bakry. Pada bulan April 1938 tamatlah tiga puluh juz.

${ }^{23}$ Mahmud Yunus dilahirkan di sebuah desa yang bernama Sungayang, Batusangkar, Sumatera Barat, pada hari Sabtu pada 10 Februari 1899M bersamaan 30 Ramadhan $1361 \mathrm{H}^{23} \mathrm{Ia}$ tumbuh di tengah-tengah keluarga terpandang dan taat beragama. Ayahnya, Yunus bin Incek adalah seorang pengajar surau. Sementara ibunya, Hafsah binti Imam Samiun, adalah anak Engku Gadang M. Tahir bin Ali, pendiri serta pengasuh surau di wilayah itu. Yang dikutip dari, Saiful Amin Ghafur, Profil Para Mufasir Al-Qur'an, (Yogyakarta: Pustaka Insan Madani, 2008), hal. 197.

${ }^{24}$ Adapun untuk ciri yang membedakan dengan tafsir yang lain yaitu, dalam tafsir ini terdapat catatan kaki, sumber penafsiran yang dipakai dari penafsiran mufasir lain, dan terdapat juga daftar surat dan isi tafsir Al-Qur'an Karim.
Karakteristik tafsir Al-Qurān Karīm karya Mahmud Yunus menggunakan metode Ijmāli (global), di mana metode ini ditandai dengan dimulai menjelaskan makna kata yang dianggap penting, menerangkan ayat yang memiliki asbāb al-nuzūl dan selanjutnya menjelaskan setiap ayat dalam Alquran dengan uraian yang tidak mendetail dan tidak menyentuh segala aspek penafsiran.

Adapun untuk contoh penafsirannya dalam tafsir Mahmud Yunus dapat dilihat berikut ini:

Q.S At-Taubah [9]: 71

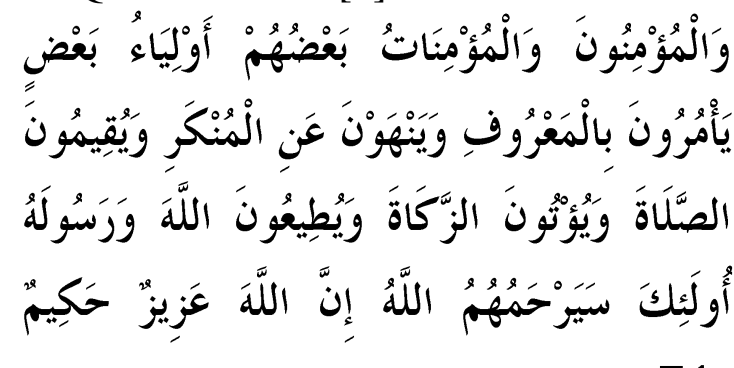

"Dan orang-orang yang beriman, lelaki dan perempuan, sebahagian mereka (adalah) menjadi penolong bagi sebahagian yang lain. mereka menyuruh (mengerjakan) yang ma'ruf, mencegah dari yang munkar, mendirikan shalat, menunaikan zakat dan mereka taat pada Allah dan Rasul-Nya. mereka itu akan diberi rahmat oleh Allah; Sesungguhnya Allah Maha Perkasa lagi Maha Bijaksana."

Tafsirannya:

Orang-orang mukmin baik laki-laki atau perempuan sebagian mereka menjadi penolong bagi yang lainnya. Mereka menyuruh yang ma'ruf dan melarang dari yang mungkar, mendirikan shalat, memberikan zakat serta mengikuti perintah Allah dan rasul-Nya. Maka orang-orang Mukmin wajib menyuruh dengan yang ma'ruf dan melarang dari yang mungkar terhadap siapa yang tidak mengikuti jalan kebenaran, meskipun pemerintah sendiri. Kezaliman-kezaliman yang dibuat orang dalam negeri, wajib kaum Muslimin memberantasnya dan 
menghilangkannya dengan sekuat tenaga. Orang-orang dapat berjuang dengan tulisannya, anggota-anggota dewan perwakilan dengan pembicaraannya dalam sidang-sidang dewan, ulama-ulama dengan perkataan dan fatwanya dan begitu seterusnya, sehingga tiap-tiap orang Islam bertanggung jawab terhadap kezaliman yang dibuat orang dalam negerinya. Apabila yang demikian tidak dilaksanakan oleh kaum Muslimin, maka Allah akan mendatangkan siksa, bukan saja kepada orang-orang yang berbuat kezaliman, melainkan ke seluruh penduduk negeri.

Ayat di atas menjelaskan bahwa setiap umat muslim hendak selalu mengajak kepada kebaikan dan melarang hal-hal yang buruk dalam bentuk apapun. Intinya saling mengingatkan kepada kebaikan dan hal itu bisa dilakukan oleh siapapun bahkan kepada atasan jika seorang budak jika memang atasannya melakukan hal-hal yang tidak benar. Berlaku juga bagi pemerintah-pemerintah, perwakilan rakyat jika memang mereka melakukan kesalahan dan menyimpang kepada hal yang tidak dibenarkan agama maka hal itu harus dicegah.

Dengan demikian dapat penulis lihat dari contoh penafsiran di atas, bahwa penjelasan tafsir yang dilakukan oleh Mahmud Yunus itu jelas menggunakan metode Ijmāli dilihat dari cara menafsirkan dimulai dengan menjelaskan makna kata dan selanjutnya menafsirkan ayat yang dianggap penting tanpa menerangkan berbagai aspek penafsiran. Selain daripada itu Mahmud Yunus ternyata menggunakan bahasa-bahasa yang erat hubungannya dengan keadaan dan kondisi zaman pra kemerdekaan di Indonesia, sebagai suatu pelajaran yang mesti diambil hikmahnya yang hendak dijelaskan oleh Mahmud Yunus.

\section{b. Tafsir Al-Furqan}

Tafsir ini ditulis oleh seorang tokoh yang bernama Ahmad Hassan (gambar 2 cover tafsir al-Furqan) $)^{25}$ yang dinamai dengan

\footnotetext{
${ }^{25}$ Nama lengkapnya adalah Hassan bin Ahmad. Ia dilahirkan di Singapura pada tahun 1887, ayahnya berasal dari India dan ibunya dari Indonesia. Lazimnya
}

"Tafsir Al-Furqan" terdiri dari satu jilid. Tafsir ini mulai ditulis pada tahun 1928. Karena penerbitannya diselingi dengan beberapa kitab yang dianggap perlu oleh anggota Persatuan Islam (Persis). Pada tahun 1941 tafsirnya baru sampai surah Maryam.

\section{Gambar 2 Cover Tafsir Al-Furqan}

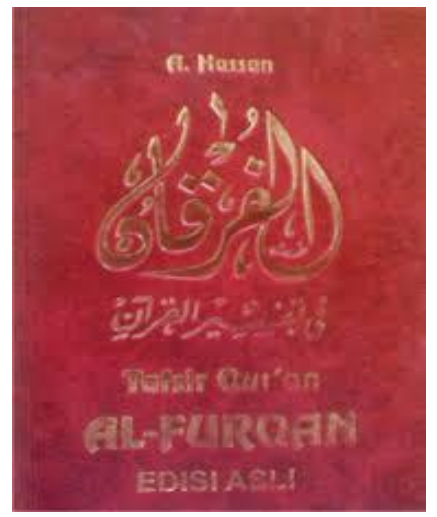

Sistematika penulisan tafsir Al-Furqān yang terdiri dari satu jilid ini yaitu dimulai dengan kata pengantar, pendahuluan, dilanjutkan dengan menuliskan pasal-pasal yang terdapat 35 pasal, ${ }^{26}$ ditambahkan oleh Abdul Qadir Hassan dengan menuliskan petunjuk tema-tema pokok dalam Alquran, daftar surah Alquran, daftar isi surah Alquran dalam bahasa Indonesia, daftar isi surah Alquran dalam bahasa Arab, dan daftar isi juz dalam Alquran. ${ }^{27}$ Kemudian baru dimulai penafsiran surah Al-Fatihah hingga Al-Nas. Ciri lainnya yakni dalam tafsir ini terdapat 4559 catatan kaki yang ditulis dalam kata pengantarnya. $^{28}$ Ini merupakan salah satu keunikan ataupun ciri dari tafsir Al-Furqān karya A. Hassan yang membedakan dengan karya tafsir lain.

Adapun untuk metode panafsirannya ialah menggunakan metode Ijmāli (global) di mana mufasir menafsirkan dengan penjelasanpenjelasan secara global tanpa penjelasan

keturunan India di Singapura, nama bapak ditaruh di depan. Ayahnya, Ahmad adalah seorang penulis, ahli kesusteraan Tamil dan ahli tentang Islam.

${ }^{26}$ Lihat. A. Hassan, Tafsir Al-Furqan, ix.

${ }^{27}$ Lihat. A. Hassan, Tafsir Al-Furqan, hal. xli dan xlvi.

${ }^{28}$ Lihat. A. Hassan, Tafsir Al-Furqan, vii. 
yang panjang lebar dan tidak menyentuh berbagai aspek penafsiran, seperti asbab alnuzul, munasabah, nasikh-mansukh, riwayatriwayat dan lain sebagainya.

Hassan menerangkan makna-makna kata yang dianggap penting untuk diterangkan. Ini sesuai dengan tujuan penulisan tafsir ini sebagaimana penulis paparkan di atas. Bahwa tujuan dari tulisannya ialah menerangkan arti tiap-tiap ayat supaya pembaca bisa faham maknanya dengan mudah.

Di bawah ini contoh penafsiran yang penulis akan tuliskan di antaranya:

Q.S Al-Imrān [3]: 169

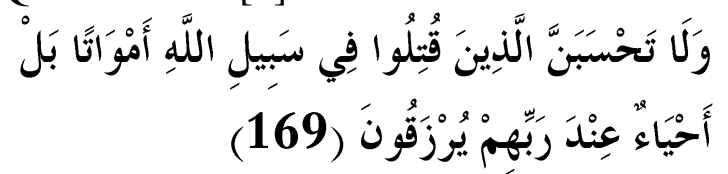

"Janganlah kamu mengira bahwa orangorang yang gugur di jalan Allah itu mati; bahkan mereka itu hidup ${ }^{29}$ disisi Tuhannya dengan mendapat rezki.,"

Tafsirannya:

Orang-orang yang mati di dalam peperangan di jalan Allah itu janganlah disangka mereka sudah mati sebagaimana orang-orang yang mati bisaa. Tidak sekali-kali! Bahkan mereka itu hidup pada pandangan Allah selama ada agama Islam, karena mereka telah korbankan jiwa-jiwa mereka untuk menyelamatkan agama Allah yang hendak dihapuskan oleh musuh-musuh Allah itu, buat mana terus ditulis amal mereka dengan tidak putus-putus sebagaimana ditulis amal orang-orang yang hidup dengan membela agama, dan di hari Kiamat kelak, diberikan kepada mereka sekalian ganjaran mereka yang dikumpulkankumpulkan itu. ${ }^{30}$

Ayat di atas menjelaskan begitu luar bisaanya orang yang jihad di jalan Allah selama dalam hati mereka ada agama Islam dan terlebih membela agama Islam.

\footnotetext{
${ }^{29}$ Yaitu hidup dalam alam yang lain yang bukan alam kita ini, di mana mereka mendapat kenikmatankenikmatan di sisi Allah, dan Hanya Allah sajalah yang mengetahui bagaimana keadaan hidup itu.

${ }^{30}$ Lihat. A. Hassan, Tafsir Al-Furqan, 140.
}

Sebagaimana para pahlawan melawan penjajah yang hendak merusak negeri ini.

Dengan demikian dapat disimpulkan seperti dapat dilihat dari contoh-contoh di atas bahwa yang dilakukan oleh A.Hassan dalam menafsirkan Alquran yaitu dengan menggunakan metode Ijmāli yang diuraikan secara singkat dan padat, untuk memudahkan pembaca dalam memahami Alquran.

\section{c. Tafsir Malja Al-Thalibin}

Tafsir ini merupakan salah satu karya pertama yang ditulis oleh Sanusi dengan bahasa daerah yaitu bahasa Sunda yang diberi nama Malja Al-Thalibin yang artinya "Panyalindungan santri-santri dina tafsiran kalamna rabb al-alamin" dan jika diterjemahkan ke dalam bahasa Indonesia, maka maknanya menjadi; "Untuk melindungi para santri dalam menafsirkan firman Allah yang ada dalam Alquran yang menguasai sekalian alam"

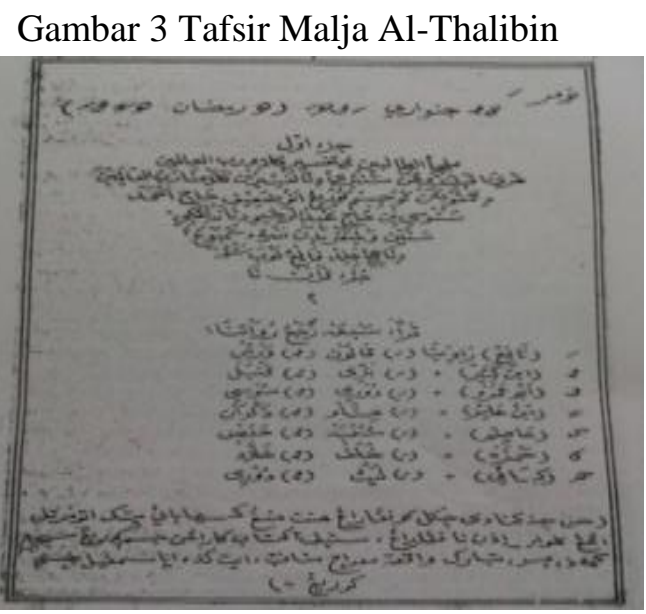

Gambar di atas menunjukan dalam tafsir ini ditulis nama-nama tujuh qira'ah sab'ah dan penulisannya dengan menggunakan Arab Pegon.

Adapun untuk metode penafsiran yang ada pada karya tafsir ini yang penulis teliti ialah menggunakan metode Ijmāli (global), di mana penafsirannya ditandai dengan langsung menerangkan dan menafsirkan penggalan kata dengan uraian yang singkat jelas, bentuk tafsirannya seperti kitab tafsir Jalalain.

\section{d. Tafsir Tamsyiah Al-Muslimin}

Tafsir ini juga merupakan karya tafsir yang ditulis oleh Ahmad Sanusi bin 
Abdoerahim, adapun untuk nama yang beliau beri ke dalam karya tafsir ke dua ini adalah Tamsjijjatoel-Moeslimien fie Tafsieri Kalami Robbil-'alamien yang beliau artikan dengan; "Menindakkan sekalian orang Islam, di dalam menafsirkan firman Toehan seroe sekalian 'alam."

Gambar 4 Tafsir Tamsyiah Al-Muslimin

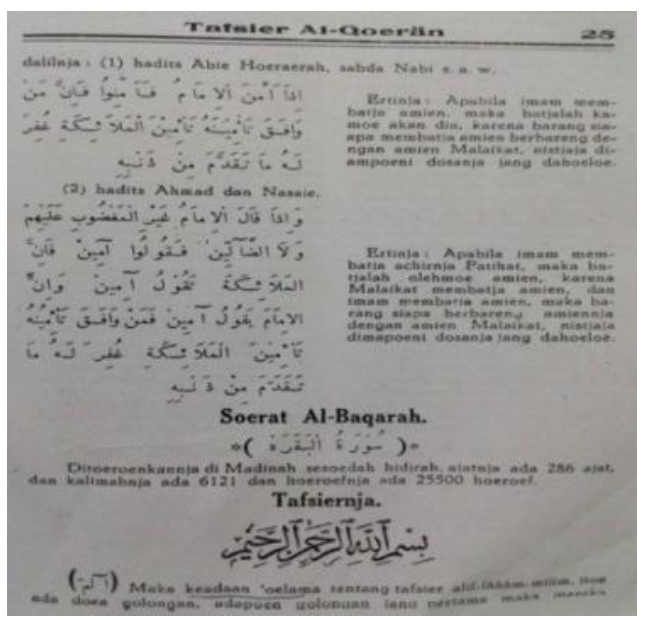

Gambar di atas menunjukkan penulisan dan metode tafsir Tamsyiah Al-Muslimin Adapun untuk metode penafsiran yang ada pada karya tafsir ini yang penulis teliti ialah menggunakan metode Tahlili (analisis), di mana penafsirannya ditandai dengan memulai menerangkan makna kata dan kemudian disambungkan dengan penafsiran yang panjang lebar ditambah dengan menambah penjelasan dalam tema tersendiri ketika ada penjelasan yang membutuhkan penjelasan yang panjang lebar. Seperti contoh di bawah ini: 85 ;

Mengenai penafsiran Q.S Al-Baqarah [2]:

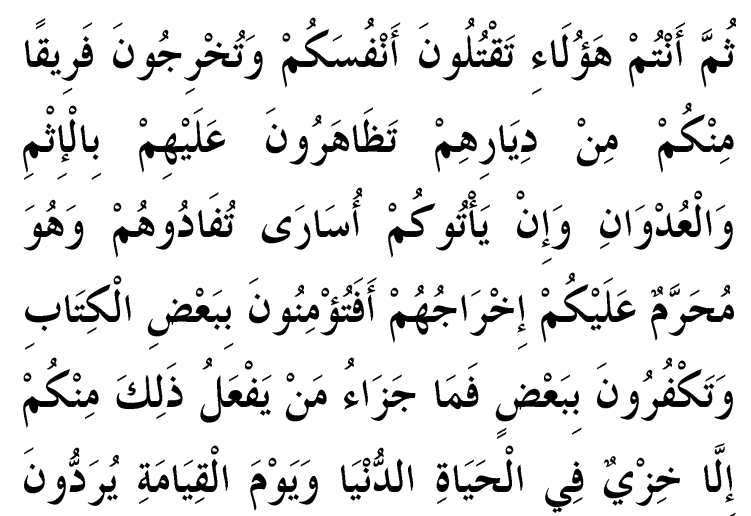

\section{إِلَى أَشَدِّ الْعَذَابِ وَمَا اللَّهُ بِغَافِلٍٍ عَمََّا تَعْمَلُونْ}

(85)

"Kemudian kamu (Bani Israil) membunuh dirimu (saudaramu sebangsa) dan mengusir segolongan daripada kamu dari kampung halamannya, kamu bantu membantu terhadap mereka dengan membuat dosa dan permusuhan; tetapi jika mereka datang kepadamu sebagai tawanan, kamu tebus mereka, padahal mengusir mereka itu (juga) terlarang bagimu. apakah kamu beriman kepada sebahagian Al Kitab (Taurat) dan ingkar terhadap sebahagian yang lain? tiadalah balasan bagi orang yang berbuat demikian daripadamu, melainkan kenistaan dalam kehidupan dunia, dan pada hari kiamat mereka dikembalikan kepada siksa yang sangat berat. Allah tidak lengah dari apa yang kamu perbuat."

Asbab al-nuzul:

Ayat Ini berkenaan dengan cerita orang Yahudi di Madinah pada permulaan Hijrah. Yahudi Bani Quraizhah bersekutu dengan suku Aus, dan Yahudi dari Bani Nadhir bersekutu dengan orang-orang Khazraj, antara suku Aus dan suku Khazraj sebelum Islam selalu terjadi persengketaan dan peperangan yang menyebabkan Bani Quraizhah membantu Aus dan Bani Nadhir membantu orang-orang Khazraj, sampai antara kedua suku Yahudi itu pun terjadi peperangan dan tawan menawan, Karena membantu sekutunya. Tetapi jika Kemudian ada orang-orang Yahudi tertawan. Maka kedua suku Yahudi itu bersepakat untuk menebusnya kendatipun mereka tadinya berperang-perangan.

Tafsirannya:

Dan Allah ta'ala mengambil atas mereka itoe, ampat perdjanjian: 1) Wadjib meninggalkan saling boenoeh satoe sama laen, 2) Wadjib meninggalkan mengoesir orang-orang daripada tempat-tempat ke diamannja. 3) Wadjib meninggalkan tolong menolong daripada sekalian satroenja. 4) Wadjib melepaskan sekalian tawanannja, akan tetapi mereka itoe berpaling pada 
ampat perdjandjian jang terseboet itoe, melainkan meneboes orang-orang tawanan, oleh karena itoe maka ditoeroenkan atas mereka itoe daripada Alloh jaitoe (apakah kamu beriman kepada sebahagian Al Kitab (Taurat) dan ingkar terhadap sebahagian yang lain?) yaitoe dengan tiada meninggalkan saling boenoeh, dan mengoesir orang-orang daripada tempattempat kediamannja, dan bertolongtolongan kepada sekalian satoenja.

Keterangan: 1) Inilah ajat menjatakan akan soeatoe ni'mat daripada beberapa ni'mat daripada Alloh atas sekalian bani Isro-il, jaitoe sekalian bani Isro-il di perentah dengan perentah-perentah jang di dalam ajat-ajat ini, dan di ambil poela perdjandjian atas mereka itoe, soepaja menjalankan segala perdjandjian itoe, serta mereka itoe menerima akan dia. 2) Ajat ini menoendjoekan atas haramja dlolim dan haramja menolong orang-orang dlolim. ${ }^{31}$

Ayat di atas yang ditafsirkan oleh Sanusi merupakan ayat yang menunjukan kepada motivasi perjuangan atau kemerdekaan Indonesia. Dengan ditambahkan penjelasan yang ia cantumkan.

Dengan demikian dapat disimpulkan metode yang dipakai dalam tafsir Ahmad Sanusi ialah metode Tah/ili dengan uraian yang panjang dan memotivasi, supaya dapat memberikan pemahaman yang jelas bagi pembaca dalam memahami Alquran.

\section{Analisis Terhadap Sumber Penafsiran \\ a. Tafsir Al-Qurān Karim}

Penulis temukan dalam tafsir ini yaitu: sumber ashliyahnya yang ada dalam tafsir Mahmud Yunus, penulis temukan ia menafsirkan suatu ayat dengan ayat lain dengan kata lain menafsirkan Alquran dengan Alquran, salah satu contohnya ketika ia menafsirkan surah Al-Baqarah [2] ayat 83. Dalam ayat ini ia menjelaskan penafsirannya

${ }^{31}$ Lihat. Ahmad Sanusi, Tamsjijjatoel Moeslimien Fie Tafsieri Kalami Robbil-'alamien, ), jilid I (Sukabumi: Al-Ijtihad, 1937, 255-257. dengan surah Al-Baqarah [2] juga pada ayat $215^{32}$

Adapun untuk tafsiran ayat Alquran dengan hadits atau riwayat Nabi salah satu contohnya dapat dilihat pada surah AlMumtahanah [60] ayat 12 dijelaskan dengan hadits riwayat Ibn 'Asakir. ${ }^{33}$ Ada juga dengan pendapat tabi' in dan ulama-ulama lain.

Dengan demikian, sumber penafsiran yang digunakan dalam tafsir Mahmud Yunus ialah bi al-Ra'yi, walaupun ia melakukan penafsiran dalam kitabnya tidak luput dengan riwayah-riwayah, qaul sahabat, qaul tabi'in, pendapat-pendapat para ulama dan mufasir lain. Ia juga menggunakan sumber penafsiran primer (mashadir ashliyah) maupun sekunder (mashadir tsanawiyah) dalam menjelaskan ayat-ayat yang ia jelaskan dalam Alquran. Namun tetap saja Mahmud Yunus memberi komentar terhadap penafsiran ayat-ayat dengan tidak keluar dari dukungan dari sumber lain, yang membuktikan bahwa upaya Yunus dalam menjelaskan ayat Alquran dengan upaya pemikirannya.

\section{b. Tafsir Al-Furqan}

Untuk sumber penafsiran yang ada pada tafsir ini ialah penulis temukan Hassan rupanya hendak menafsirkan Alquran dengan Alquran sebagaimana dalam tafsirnya salah satu contohnya; surah Al-Baqarah [2] ayat 60 ditafsirkan dengan surah Al-'Arāf[7] ayat $160 .^{34}$ Ada juga penafsiran Hassan yang diperkuat dengan pemdapat ulama, seperti contoh dalam surah Al-' Arāf[7] ayat 54. ${ }^{35}$

Untuk sumber yang penulis temukan dapat disimpulkan bahwa Hassan menggunakan sumber bi al-Ra'yi dalam penafsirannya, terlihat dari setiap ayat yang ditandai dengan catatan kaki ia menafsirkan dengan pengetahuan atau ijtihadnya yang ia ketahui tanpa menyimpang dengan aturanaturan yang ada dalam penafsiran. Namun walaupun demikian, ada juga penafsiran yang

\footnotetext{
${ }^{32}$ Lihat. Mahmud Yunus, Tafsir Al-Qur'an Karim, 17.

${ }^{33}$ Lihat. Mahmud Yunus, Tafsir Al-Qur'an Karim, 825 .

${ }^{34}$ Lihat. A. Hassan, Tafsir Al-Furqan, 16.

${ }^{35}$ Lihat. A. Hassan, Tafsir Al-Furqan, 302.
} 
diperkuat dengan ayat atau surah lain dan pendapat ulama atau mufasir lain, akan tetapi itu hanya ada di beberapa ayat saja. Beliau mencantumkan makna tiap kata yang dianggap penting untuk disampaikan, dan mencatumkan $a s b \bar{a} b$ al-nuzūl pada ayat yang memilikinya.

\section{c. Tafsir Malja Al-Thalibin}

Dalam tafsir ini sumber yang penulis temukan ialah menggunakan sumber bi al$R a^{\prime} y \bar{i}_{s}$ di mana penafsirannya itu menggunakan ijtihad yang didasarkan pada keterangan ayat lain, dan juga banyak mencantumkan sumber hadits-hadits Nabi saw, serta pendapat ulama dan mufasir lain. Seperti contoh dalam menerangkan mengenai "Membaca Amin setelah Al-Fatihah" di sana terdapat hadits Nabi saw., yang diriwayatkan dari Abi Hurairah, ${ }^{36}$ sebagai dukungan bagi penafsirannya.

\section{d. Tafsir Tamsyiah Al-Muslimin}

Dalam tafsir ini, yang penulis teliti rupanya sama seperti tafsir sebelumnya, bahwa Sanusi menggunakan sumber bi alRa'yi dalam menafsirkan ayat-ayat. Namun walaupun ia menjadikan sumber pijakan dengan ra'yi akan tetapi tidak selamanya pada ijtihadnya, ia juga menggunakan dan mencantumkan penjelasan ayat-ayat lain, menuliskan banyak hadits-hadits yang mendukung, serta pendapat ulama dan mufasir lain dalam penafsirannya itu.

\section{Analisis Terhadap Corak Penafsiran \\ a. Tafsir Al-Qurān Karīm}

Corak penafsiran biasanya diartikan warna penafsiran atau dengan kecenderungan yang ada dalam penafsiran seorang mufasir dalam tafsinya, sebagaimana yang telah penulis paparkan pada bab sebelumnya.

Untuk corak yang terdapat dalam tafsir ini, penulis menyimpulkan bahwa corak penafsiran yang lebih dominan adalah corak adab al-ijtima', di mana corak ini lebih menjelaskan mengenai kondisi sosial yang tengah dihadapi masyarakat pada waktu itu. Kebanyakan dari penjelasan tiap ayat dan surah itu ditafsirkan dulu kemudian

\footnotetext{
${ }^{36}$ Lihat. Ahmad Sanusi, Malja Al-Thalibin, 15.
}

dilanjutkan dengan menghubungkan penjelasan kondisi keadaan Indonesia serta mengambil petunjuk-petunjuk dari ayat Alquran dan pelajaran serta hikmah-hikmah dari kisah-kisah umat terdahulu, asbab nuzul, riwayat-riwayat. Walaupun Yunus seorang ulama yang ahli bahasa Arab sebagaimana latarbelakang pendidikannya mengambil jurusan Bahasa Arab, namun ia tidak menafsirkan setiap ayat dengan kecenderungan bahasa (lughawi) sesuai keahliannya. Akan tetapi ia tetap menjelaskan makna kata yang dianggap penting untuk dijelaskan.

\section{b. Tafsir Al-Furqan}

Dalam tafsir ini penulis menyimpulkan mengenai corak penafsiran yang ada ialah bercorak lughawi, di mana penafsiran yang ia gunakan banyak membahas makna-makna kata yang dijelaskan dengan kaidah-kaidah kebahasaan sesuai dengan yang beliau ketahui. Walaupun penafsiran yang beliau jelaskan hanya mencakup uraian yang umum atau global saja.

Contoh penfsiran yang menunjukkan kepada kebahasaan:

Q.S Al-Baqarah [2]: 1;

"Alif laam miin.",37

Tafsirannya:

Menurut sebagian dari tafsir-tafsir, bahwa:

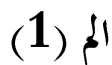

${ }^{37}$ Ialah huruf-huruf abjad yang terletak pada permulaan sebagian dari surat-surat Al Quran seperti: Alif laam miim, Alif laam raa, Alif laam miim shaad dan sebagainya. di antara ahli-ahli tafsir ada yang menyerahkan pengertiannya kepada Allah Karena dipandang termasuk ayat-ayat mutasyaabihaat, dan ada pula yang menafsirkannya. golongan yang menafsirkannya ada yang memandangnya sebagai nama surat, dan ada pula yang berpendapat bahwa hurufhuruf abjad itu gunanya untuk menarik perhatian para Pendengar supaya memperhatikan Al Quran itu, dan untuk mengisyaratkan bahwa Al Quran itu diturunkan dari Allah dalam bahasa Arab yang tersusun dari hurufhuruf abjad. kalau mereka tidak percaya bahwa $\mathrm{Al}$ Quran diturunkan dari Allah dan Hanya buatan Muhammad s.a.w. semata-mata, Maka cobalah mereka buat semacam Al Quran itu. 
1) "Alif" ringkasan atau potongan huruf dari kalimah "Allah" atau "Ana" (Aku).

2) "Lam" itu ringkasan atau potongan huruf dari "Jibril", "Allah", atau "Lathif" (Pemanis, Pelemah lembut).

3) "Mim" itu ringkasan dai potongan huruf dari "Muhammad", "A'lam" (Yang terlebih mengetahui), atau "Majid" (Yang amat mulia atau Yang amat dijunjung). Maka "Alif" "Lam" "Mim" itu bisa dirangkai bermacammacam:

4) Allah, Jibril, Muhammad.

5) Aku, Allah Yang terlebih mengetahui.

6) Allah, Pelemah lembut, Yang amat mulia.

7) Jadi maksudnya bahwa: Alquran ini dari Allah kepada Jibril, kepada Muhammad.

8) Alquran ini daripadaKu, Allah yang terlebih mengetahui.

9) Alquran ini dari Allah Pelemah lembut, Yang amat mulia. ${ }^{38}$

Ayat ini, menjelaskan mengenai hurufhuruf muqattha'ah dalam ayat yang termasuk ayat mutasyabihat. Dengan menguraikan kosa kata atau kajian kebahasaan mengenai hurufhuruf tersebut. Dari penafsiran di atas telihat bahwa Hassan mencoba menjelaskan tiap-tiap huruf dengan kaidah yang ada dalam bahasa Arab sesuai dengan apa yang beliau ketahui dengan mengerahkan segala pengetahuannya.

\section{c. Tafsir Malja Al-Thalibin}

Pada karya tafsir ini terlihat juga dalam penjelasan tafsirannya corak yang menonjol pada penafsiran ini adalah umum, tidak bisa ditentukan secara pasti apa corak yang menonjol dalam kitab ini. Karena terlihat dalam penafsirannya beliau terkadang menjelaskan penafsiran yang menyangkut hal yang bernuansa fiqih, teologi, dll seperti terlihat pada halaman 12 yang menjelaskan mengenai hukum membaca Al-Fatihah dalam shalat.
Sebagimana contoh penafsiran Ahmad Sanusi dalam tafsir Malja Al-Thalibindapat dilihat di bawah ini.

1) Corak kalamidalam Tafsir Malja AlThalibin misalnya ketika Ahmad Sanusi memberikan pengantar seputar Alquran, Sanusi menjelaskan bagaimana posisi dan kedudukan kitab suci tersebut:

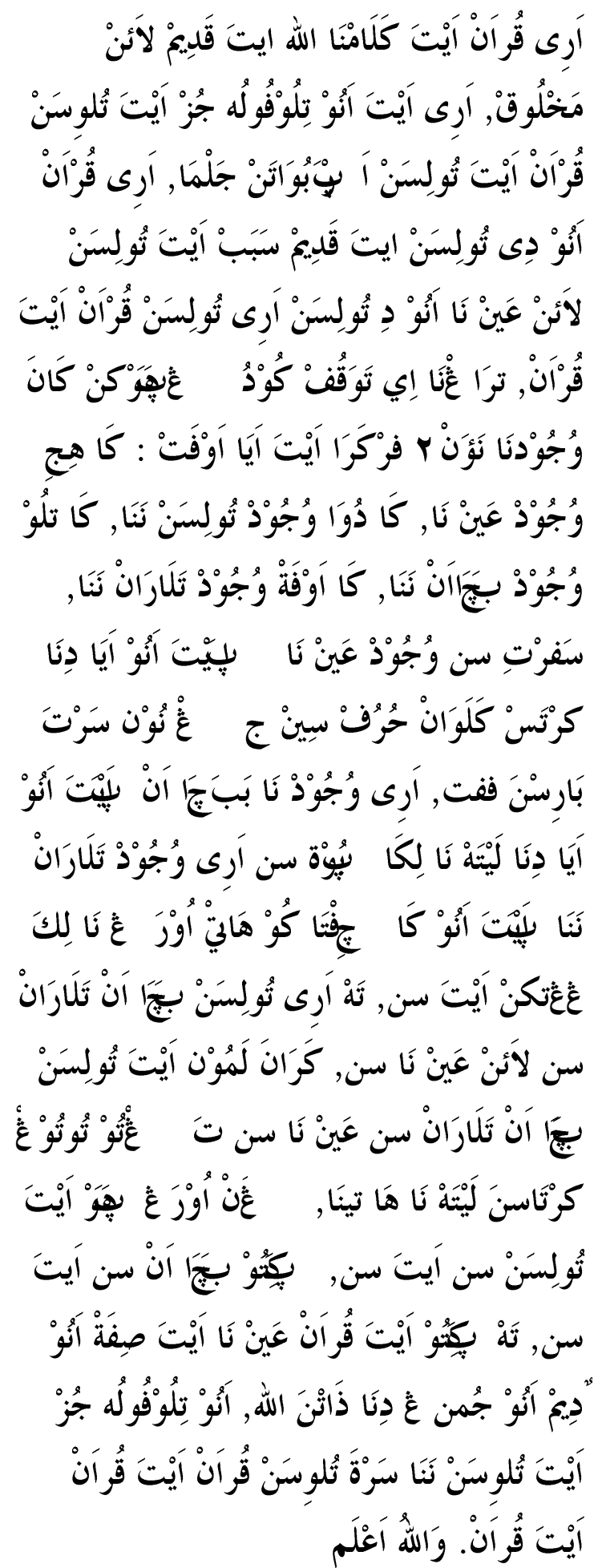

\footnotetext{
${ }^{38}$ Lihat. A. Hassan, Tafsir Al-Furqan, 2.
} 
Kutipan ini menunjukan secara jelas sikap Sanusi sebagai pembela Aswaja dalam bidang teologi, khususnya dalam menyikapi masalah kedudukan Alquran. Secara teologis, madzhab Aswaja menganut ajaran bahwa Alquran bukan makhluk. Ini berseberangan dengan kelompok Mu'tazilah yang melalui teologi rasionalnya menempatkannya sebagai makhluk dan karenanya berlaku hukum sejarah atasnya. Sekte yang lahir di saat perdebatan teologi berjalan dengan bebas ini mencoba mengajukan pandangan bahwa Alquran adalah mushaf yang diciptakan oleh ruang dan waktu tertentu, sehingga kedudukannya adalah profan. Melalui perspektif ini, kalangan Mu'tazilah menempatkan Alquran itu sepenuhnya sebagai bacaan independen yang memberikan ruang interpretasi secara bebas, tanpa kungkungan dokttinal apapun. Sanusi sebagai ulama yang memegang teguh ideologi Aswaja tentu saja berkepentingan untuk menegaskan sikapnya atas masalah ini.

2) Corak fiqih Ahmad Sanusi dalam Tafsir Malja Al-Thalibin, sebagaimana terdapat penafsiran pada hukum membaca surat Al-Fatihah [1]: 1-7

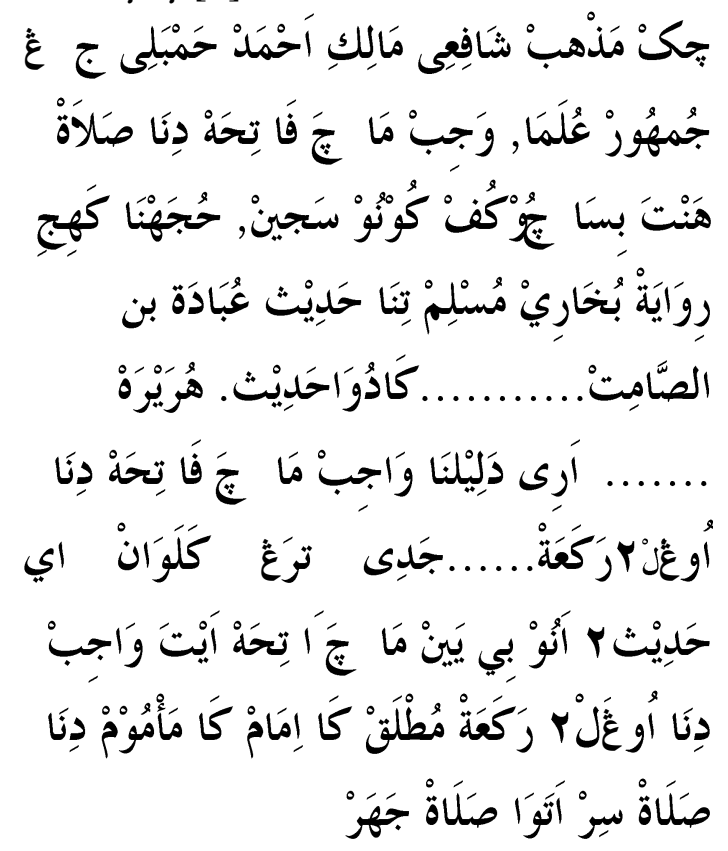

Menurutnya, membaca Al-Fatihah ketika shalat hukumnya wajib menurut madzhab al-Syafi'i, Maliki, Hanbali, dan jumhur ulama. Kewajiban membaca surat Al-
Fatihah ini tidak bisa diganti dengan membaca surat lain. Tafsir Malja AlThalibin bahkan memaparkan banyak hadits-hadits mengenai keharusan membaca Al-Fatihah dalam shalat. Hadits-hadits itu jelas menunjukkan kewajiban membacanya dalam setiap rakaat baik imam atau makmum, nyaring atau pelan-pelan.

3) Corak sufi Ahmad Sanusi dalam Tafsir Malja Al-Thalibin, sebagaimana terdapat penafsiran pada surat Al-Fatihah [1]: 1-7

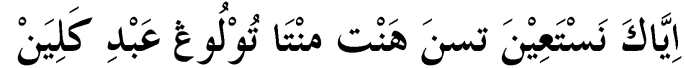

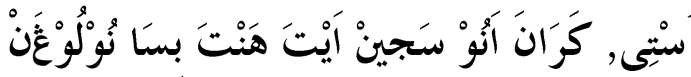

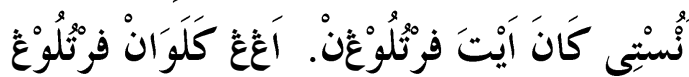

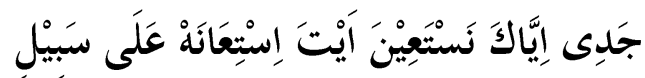

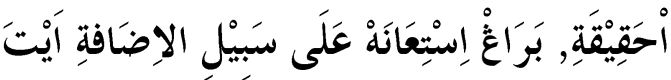

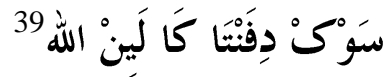

Dapat disimpulkan dari contoh-contoh di atas bahwa corak yang terdapat pada tafsir Malja Al-Thalibin ini tidak dapat dipastikan apakah coraknya itu fiqih, falsafi, lughawi atau yang lainnya. Adakalanya Sanusi menafsirkan ayat yang berhubungandengan masalah fiqih, kalam, atau sufi.Dengan demikian coraknya bersifat umum.

\section{d. Tafsir Tamsyiah Al-Muslimin}

Dalam penafsiran kitab tafsir ini penulis menemukan bahwa corak yang ada pada tafsir ini yakni adab al-ijtima' $i$, di mana penafsiran yang ada menunjukkan kepada halhal yang bersangkutan pada hal yang bersangkutan sosial kemasyarakatan yang sedang terjadi. Juga, karena tafsir ini ada di zaman masa pra kemerdekaan tentu saja ada sedikitnya bahasa yang digunakannya dengan memotivasi pada semangat perjuangan Indonesia. Seperti pada surah Al-Baqarah [2] ayat 85 di sana ada bahasa atau menunjukan kepada semangat untuk merdeka.

${ }^{39}$ Yuliawati, "Karakteristik Tafsir Malja AlThalibin (studi pada sumber, metode dan corak tafsir)" , S-1 Kearsipan Fakultas Ushuluddin, UIN Bandung, 2016, 87-89. 


\section{Ciri Khas Penafsiran pada Karya-Karya Tafsir Tahun 1900-1945}

Setelah penulis meneliti mengenai metode, sumber dan corak penafsiran pada keempat karya tafsir masa itu. Maka setelah itu,selanjutnya penulis menemukan mengenai ciri khas yang terdapat pada semua karya tafsir tersebut. Singatnya ciri khas adalah sesuatu yang dapat dibedakan dengan yang lain. Dalam hal ini, mengenai ciri khas yang terdapat pada keempat karya tafsir yang ada pada masa itu ialah kental dengan keadaan sosio-politik di mana masyarakat Indonesia berada dalam keadaan yang cukup rumit, karena keadaan mereka pada saat itu dalam keadaan terjajah, ditambah dengan masalahmasalah yang lainnya seperti masalah internal yang terjadi pada masyarakat Indonesia dengan munculnya berbagai gerakan dari organisasi-organisasi.

Dengan lahirnya karya-karya tafsir tersebut menunjukkan bahwa sedikitnya penafsiran-penafsiran para mufasir Indonesia mempunyai niat untuk memberikan motivasi melalui karya tulisan mereka yang berupa karya tafsir, walaupun hanya dengan pernyataan-pernyataan yang samar-samar. Ini dapat dibuktikan dengan melihat corak penafsiran karya-karya tersebut pada arah sosial kemasyarakatan.

Dengan demikian, ciri khas pada karya tafsir tahun 1900-1945 kental dengan keadaan sosio-politik. Pada keempat tafsir ini karena berada pada masa pra kemerdekaan, tentu saja di dalam penafsirannya ada sedikitnya ayatayat yang menyentuh mengenai motivasi pada semangat perjuangan seperti misal contoh yang ada pada ayat 85 surah Al-Baqarah dan ayat 71 surah Al-Taubah, yang membuktikan bahwa penulisan karya tafsir pada masa ini ada kaitannya dengan persoalan sosio-politik yang terjadi dan bahkan dapat menjurus kepada jawaban-jawaban dari masalah yang terjadi, yang merupakan suatu ciri khas dari karya-karya tafsir masa itu.

\section{SIMPULAN}

Berdasarkan dari penelitian yang telah penulis teliti adalah bahwa dalam perkembangannya tafsir dari abad ke abad mengalami perkembangan dilihat dari banyaknya karya tafsir yang dihasilkan, struktur penulisan, mufasir serta dari hal spesifik mengenai karakteristik penafsiran yang telah penulis teliti dari segi metode, sumber dan corak penafsiran yang ada pada karya-karya tafsir tahun 1900-1945 di Indonesia pada masa pra kemerdekaan.

Adapun untuk karya tafsir yang ada dan telah penulis teliti di antaranya; Tafsir Mahmud Yunus (Alquran al-Karim), Tafsir A. Hassan (Al-Furqan), Tafsir Ahmad Sanusi (Malja Al-Thalibin dan Tamsyiah AlMuslimin). Maka pada keempat tafsir yang berada pada masa kemerdekaan Indonesia yang dilihat dari segi karakteristik metode, sumber dan corak penafsiran itu untuk kesimpulan yang dapat diambil dari penelitian ini dapat diuraikan sebagai berikut:

1. Metode

Untuk metode penafsiran yang ada pada ke dua tafsir yaitu Alquran al-Kari, AlFurqāndan Malja Al-Thalibin adalah metode Ijmāli (global), di mana penjelasan tafsirannya itu bersifat global atau umum, uraiannya singkat padat dengan penjelasan yang mudah dipahami oleh pembaca. Sedangkan pada karya Ahmad Sanusi yaitu Tamsyiah AlMuslimin adalah metode Tahlili, di mana penafsiran yang ada dalam kedua karya tersebut penjelasannya banyak yang dijelaskan dengan rinci dan menyentuh aspek lain selain seperti, qira'ah sab'ah dll.

2. Sumber

Sumber penafsiran yang ada pada ke empat karya tafsir ini seluruhnya menggunakan tafsir yang berpijak pada ijtihad mufasir, dengan kata lain menggunakan sumber bil ra'yi di mana penafsirannya itu banyak ditafsirkan oleh pemahaman dan pengetahuan mufasir dengan mengunggkap isi kandungan yang ada pada ayat-ayat Alquran. Namun pada dasarnya semua karya-karya tafsir itu tetap menuliskan sumber-sumber lain, dengan tidak mengesampingkan sumbersumber lain seperti ayat-ayat lainnya yang mendukung pada penafsiran yang dijelaskan, hadits-hadits nabi, keterangan sahabat dan 
tabiin, pendapat ulama dan mufasir lain sebagai dukungan dalam memperkuat tafsirannya.

3. corak

Dalam segi corak penafsiran yang dapat diketahui penulis dari keempat karya tafsir ini ialah berbeda, untuk tafsir Alquran Al-Karim karya Mahmud Yunus adalah corak adab alijtima, di mana penulis melihat dari penafsirannta itu banyak uraian yang dikaitkan dengan apa yang terjadi pada kejadian sosial kemasyarakatan yang sedang terjadi pada masa itu. Pada tafsir Al-Furqan, corak yang penulis telah teliti lebih ke corak lughawi, sebab Hassan senantiasa ketika menjelaskan makna tata kebahasaan dengan lebih detail. Untuk tafsirini seperti halnya tafsir Mahmud Yunus yaitutafsir Tamsyiah Al-Muslimin adalah bercorak adab al-ijtima'i maksudnya coraknya lebih membahas dan mengaitkan penafsirannya dengan sosial kemasyarakatan sebagai tujuan dari menjawab persoalan yang sedang terjadi di kala itu. Adapun pada karya tafsir Malja Al-Thalibhincorak yang terdapat dalam tafsir ini tidak ada yang dominan, dengan demikian corak yang ada dalam tafsir ini adalah bersifat umum.

Dengan demikian, pada keempat tafsir ini karena berada pada masa pra kemerdekaan, tentu saja di dalam penafsirannya ada sedikitnya ayat-ayat yang menyentuh mengenai motivasi pada semangat perjuangan seperti misal contoh yang ada pada ayat 85 surah Al-Baqarah dan ayat 71 surah AlTaubah, yang membuktikan bahwa penulisan karya tafsir pada masa ini ada kaitannya dengan persoalan sosio-politik yang terjadi dan bahkan dapat menjurus kepada jawabanjawaban dari masalah yang terjadi, yang merupakan suatu ciri khas dari karya-karya tafsir masa itu.

\section{DAFTAR PUSTAKA}

Amal, Taufik Adnan dkk. Tafsir Kontekstual Alquran. Bandung: Mizan, 1990.

Amin Aziz, M. "Karakteristik Tafsir di Indonesia Abad Keduapuluh," Jurnal Ilmu Dan Kebudayaan Ulumul Quran.Jakarta: Lembaga Studi Agama dan Filsafat (LSAF) dan Ikatan Cendikiawan Muslim se Indonesia, Volume III. No. 4, 1992.

Baidan, Nashiruddin. Metodologi Penafsiran Alquran. Yogyakarta: Pustaka Pelajar, 1998.

Perkembangan Tafsir

Alquran di Indonesia. Yogyakarta:

Pustaka Mandiri, 2003.

Darmawan, Dadang. "Pengaruh

Pembaharuan Terhadap Perkembangan

Tafsir di Indonesia Tahun 19001945"(laporan penelitian). Fakultas Ushuluddin, UIN Sunan Gunung Djati Bandung, 2013.

Al-Dzahabi,Muhammad Husein.Al-Tafsir Wa Al-Mufasirun. Maktabah Wahbah: AlQahirah,2000.

Eni Zulaiha, dan Badruzzaman M. Yunus.Metodologi Tafsir Klasik. tt.th. tp.

Al-Farmawi, Abdul Hayy.Metode Tafsir Maudhu'i dan Cara Penerapannya, terj. Rosihon Anwar. Bandung: CV. Pustaka Setia. 2002.

Al-Fatih, Suryadilaga, dkk.Metodologi Ilmu Tafsir. Yogyakarta: Teras, 2010.

Gusmian, Islah.Khazanah Tafsir Indonesia: dari Hermeneutika Hingga Ideologi. Jakarta: Teraju, 2003.

Hassan, A, Tafsir Al-Furqan.Bangil: UD. Pustaka Tamaam,2014.

Ibrahim, Sulaiman. Pendidikan dan Tafsir "Kiprah Mahmud Yunus dalam Pembaruan Islam. ”Jakarta: LEKAS, 2001.

Izzan, Ahmad. Metodologi Ilmu Tafsir. Bandung: Tafakur,2011.

Kholid, Abd. Kuliah Madzahib Al-Tafsir. IAIN Sunan Ampel Surabaya: Fakultas Ushuluddin, 2003.

Mustaqim, Abdul.Aliran-Aliran Tafsir; dari Periode Klasik Hingga Kontemporer. Yogyakarta: Kreasi Warna, 2005.

Al-Qaththan, Manna. Mabahits fi Ulum Alquran, Terj: Aunur Rafiq el-Mazni. Jakarta: Pustaka al-Kautsar, 2006. 
Sanusi, Ahmad. Tamsjijjatoel Moeslimien Fie Tafsieri Kalami Robbil-'alamien. Sukabumi: Al-Ijtihad, 1937.

Shihab, M. Quraish.Membumikan Alquran.Bandung: Mizan, 1992.

Yuliawati, "Karakteristik Tafsir Malja AlThalibin (studi pada sumber, metode dan corak tafsir)" (skripsi). Jurusan Tafsir Hadits Fakultas Ushuluddin, UIN Sunan Gunung Djati Bandung, 2016.
Yunus, Mahmud. Sejarah Pendidikan Islam di Indonesia. Jakarta: Hidakarya Agung,1984.

$$
\text { Tafsir Qur'an }
$$

Karim.Jakarta: PT. Mahmud Yunus Wa Dzurriyah, 2011.

Yusuf, Kadar M. Study Alquran. Jakarta: Amza, 2009

Zuhdi, M. Nurdin.Pasaraya Tafsir Indonesia.Yogyakarta: Kaukabapa, 2014. 